\title{
Gender Equity in Intercollegiate Athletics: Determinants of Title IX Compliance
}

\section{Introduction}

The year 2002 marked the 30th anniversary of the passage of Title IX, which prohibits discrimination by gender in any federally funded educational activity. Although the scope of Title IX includes all aspects of education, the application of Title IX to college athletics has been especially complicated because athletics programs, unlike most academic classes, usually are sex-segregated by sport. As explained in more detail below, Title IX essentially requires that all institutes of higher education provide student access to sport participation on a gender-neutral basis. As a result, athletic opportunities for female undergraduates have expanded significantly since 1972. For example, the female share of college athletes rose to $42 \%$ in $2001 / 02$ from only $15 \%$ in 1972 (U.S. Department of Education, 1997, 2003). Despite this

Deborah Anderson is Assistant Professor in the Educational Leadership Program at the University of Arizona. John Cheslock is Assistant Professor at the Center for the Study of Higher Education at the University of Arizona. Ronald Ehrenberg is the Irving $M$. Ives Professor of Industrial and Labor Relations and Economics at Cornell University and Director of the Comell Higher Education Research Institute.

We thank the following people for assistance: Amaury Nora, Ron Oaxaca, Michael Oivvas, J. Douglas Toma, participants in 2002 IHELG Finance Roundtable, and three anonymous referees for helpful comments and suggestions; Yan Xie for excellent research assistance; Don Sabo and the Women's Sports Foundation for providing 1995/96 EADA data; Pamela Maimer at the Department of Education for providing 2001/02 EADA data; Tammy Smith at the NCAA for providing division, football, and track and field/cross-country data.

The Journal of Higher Education, Vol. 77, No. 2 (March/April 2006)

Copyright $\odot 2006$ by The Ohio State University 
progress, gender equity is far from complete. Estimates from our data show that at the average institution in 2001/02, women comprised 55\% of all students but only $42 \%$ of the varsity athletes.

Our research describes the level of noncompliance with Title IX, as measured by the proportionality gap, between $1995 / 96$ and 2001/02, and then investigates why some institutions perform better than others do on this measure of gender equity. One important contribution of this article is the introduction of a new data set developed by the authors that includes information on athletic offerings and other institutional characteristics for the 1995/96 and 2001/02 academic years. Our data represent a substantial improvement over previous data because we include institutions in Divisions I, II, and III and adjust for changes in how institutions report athletic participation over the period; previous research focused solely on Division I institutions and did not adjust for reporting differences. We show that these data differences are important: Reliance on unadjusted data from Division I institutions results in large overestimates of the improvement in compliance at NCAA institutions during the late 1990s. Our data also include a rich set of explanatory variables that we use in regression analyses to explain the extent of institutional noncompliance. We examine the determinants of the proportionality gap by estimating OLS cross-section regressions (with and without conference fixed effects) at two points in time (1995/96 and 2001/02) and firstdifference regressions for changes over the period.

Using Equity in Athletics Disclosure Act (EADA) data for approximately 700 institutions in Divisions I, II, and III, we find that noncompliance (in terms of women being underrepresented among athletes) decreases from about $90-93 \%$ of the sample in $1995 / 96$ to about $82-89 \%$ of the sample in 2001/02, allowing for leeway of 3-5 percentage points in measuring proportionality. However, by the end of the period, the vast majority of institutions, especially in Divisions II and III, remain out of compliance with an average gap of $13 \%$ for all institutions. Interestingly, the greatest compliance and the most improvement in compliance are seen among institutions in Division I, especially I-A schools who participate in the Bowl Coalition Series (BCS). Our regression results show that several institutional characteristics are associated with a large proportionality gap, all else equal: location in the Midwest and South (relative to West); larger share of undergraduates who are female; and having a football team. On the other hand, more selective institutions (as measured by Barron's selectivity ranking), larger institutions, and institutions with greater funds--especially high tuition and fees-are found to have smaller proportionality gaps, all else equal. 
Literature Review

\section{A Brief History of Title IX}

In 1972, the U.S. Congress passed Title IX of the Educational Amendments to the 1964 Civil Rights Act. It states in part:

No person in the United States shall, on the basis of sex, be excluded from participation in, be denied the benefits of, or be subjected to discrimination under any educational program or activity receiving federal financial assistance. (Office for Civil Rights, 1979).

The initial interpretation of Title IX's application to intercollegiate athletics was issued by the Department of Health, Education, and Welfare (HEW), now referred to as Health and Human Services (HHS), in 1975 with a deadline for institutional compliance delayed until 1978. However, because these regulations were felt by many universities to be "vague and inadequate" (Johnson, 1994), the Office for Civil Rights (OCR) developed a more complete policy interpretation in 1979. Several more recent policy clarifications, discussed below, were released by OCR to address continuing uncertainty.

Although Title IX was passed in 1972, the seriousness with which institutions considered this law while planning their athletics programs has varied over time with different court rulings and additional legislation. Institutions of higher education were at first unsure whether Title IX even pertained to intercollegiate athletics. This uncertainty was temporarily resolved in 1984 when the Supreme Court ruled in Grove City College v. Bell that Title IX only applied to those specific programs that received federal aid, exempting athletics from the reach of the law. However, Congress clarified its intent in 1988 with the Civil Rights Restoration Act, which mandated that all programs at a federally funded institution be subject to Title IX.

Efforts to ensure compliance with Title IX grew during the 1990s. First, in 1992, the Supreme Court held in Franklin v. Gwinnett County Public Schools that monetary damages may be awarded to a plaintiff if the violation of Title IX was intentional. Next, Congress passed the Equity in Athletics Disclosure Act in 1994, mandating that institutions release data on the operation of men's and women's sports programs. We use data collected under this legislation as the basis for our analyses below. Further, the Clinton administration enforced Title IX more aggressively than did previous administrations. Perhaps the most important factor was the pivotal case of Cohen v. Brown University. The U.S. Supreme Court denied certiorari in 1997, upholding the First Circuit 
Court of Appeals's decision to "require [Brown] university to adhere to strict criteria for demonstrating gender equity in intercollegiate athletics" (Thelin, 2000, p. 391). Because Brown University offered more women's sports teams than any other school in the country besides Harvard, this ruling made institutions less confident in their ability to defend themselves against a Title IX lawsuit (Shulman \& Bowen, 2001).

\section{Current Legal Interpretations of Title IX}

With respect to intercollegiate athletics, Title IX applies to three broad areas: financial assistance to athletes; "other program areas" such as "treatment, benefits, and opportunities" for intercollegiate athletes; and "equal opportunity (equally effective accommodation of the interests and abilities of male and female athletes)" (Johnson, 1994, p. 558). Focusing on the third area of "equal opportunity," the 1979 OCR policy interpretation describes several factors to consider when determining compliance. One of these factors deals with the provision of competitive opportunities in order to accommodate the interests and abilities of male and female athletes. It is in reference to this factor that the OCR developed the following three-prong test that is most commonly associated with Title IX's application to intercollegiate athletics (Johnson, 1994):

Part One: Substantial Proportionality. This part of the test is satisfied when participation opportunities for men and women are "substantially proportionate" to their respective undergraduate enroliments.

Part Two: History and Continuing Practice. This part of the test is satisfied when an institution has a history and continuing practice of program expansion that is responsive to the developing interests and abilities of the underrepresented sex (typically female).

Part Three: Effectively Accommodating Interests and Abilities. This part of the test is satisfied when an institution is meeting the interests and abilities of its female students even where there are disproportionately fewer females than males participating in sports. (U.S. Department of Education, 1997)

From a practical standpoint, the rulings in Cohen v. Brown University, Roberts v. Colorado State University, and Favia v. Indiana University of Pennsylvania make clear that "the three-part test for competitive opportunities seems to have become the key to judicial evaluation of compliance with Title IX's athletic regulations" (Johnson, 1994, p. 580). Therefore, this article (following the related empirical literature) will focus on the three-prong test as a measure of gender equity in intercollegiate athletics. Furthermore, although noncompliance requires failure of all three prongs, in practice it will be very difficult for any university to rely on passing the second or third prong (see, for example, Farrell, 1995; Johnson, 
1994; Sigelman \& Wahlbeck, 1999; Stafford, 2004). As demonstrated in Cohen v. Brown, institutions have not been successful in relying upon the third prong requiring the effective accommodation of students' interests and abilities. Meanwhile, reliance upon the second prong requires a "continuing (i.e. present) practice of program expansion" (Office for Civil Rights, 1996, p. 6), so it only can be a temporary solution. As a result, it seems that "substantial proportionality' has become the irrebuttable test for determining whether a school discriminates in its athletic program" (Mahoney, 1995, p. 976-977). Even more convincing are the 1996 OCR policy clarification and the words of the court in Cohen $v$. Brown University, both of which referred to substantial proportionality as a "safe harbor." Although the favored status of the first prong was recently diminished in a July 2003 OCR policy clarification, the Department of Education did not provide additional guidance regarding how institutions can comply with the second or third prong; as a result, the most recent clarification did not diminish the importance of substantial proportionality.

Because the first prong is so prominent, it is important to understand exactly how it is used to measure compliance. The OCR has declined to define what gap (between the percentage of athletes who are female and the percentage of undergraduates who are female), if any, would be considered "substantially proportionate" under Title IX. In recent cases, no court has specified what range of gaps would be admissible under the "substantial proportionality" standard, although it is clear that $10.5 \%$ is too big while a gap as large as $1.7 \%$ is acceptable (Roberts v. Colorado State University). However, several lawsuit settlements suggest that a gap of $3 \%$ or $5 \%$ would be acceptable to a court of law (Farrell, 1995).

\section{Summary and Critique of Related Empirical Literature}

Despite the prominence of Title IX in intercollegiate athletics in recent policy debates, little quantitative work has investigated which institutional characteristics are associated with compliance as measured by the first prong of "substantial proportionality." Several works focus on other aspects of gender equity in athletics. For example, Zimbalist (1997) describes overall trends in the number of sports teams, scholarship aid to athletes, and coaching salaries by gender. Thelin (2000) takes a historical approach and shows that compliance with gender equity has not caused undue financial strain on Division I athletic programs (as was claimed by some institutions). His results also suggest that Division I athletic departments would not, absent legislative mandate, voluntarily provide data necessary to evaluate gender equity. Carroll and Humphreys (2000) use multinomial logistic regression to estimate 
which Division I institutions increased, decreased, or left unchanged the number of men's team offerings between 1990 and 1995 . They find that size of institution and expenditure on men's athletics are positively correlated while membership in Division I-A is negatively correlated with the probability of decreasing men's teams. Rishe (1999) focuses on gender equity in athletic expenditures, but also examines factors correlated with compliance in athletic participation. He calculates the average proportionality gap, defined as the percentage of athletes who are female minus the percentage of undergraduates who are female, across regions and type of institution. His results show that institutions with football teams, institutions in the South, and historically Black colleges and universities have larger proportionality gaps.

Only three studies (Agthe \& Billings, 2000; Sigelman \& Wahlbeck, 1999; Stafford, 2004) have examined the determinants of compliance in a regression framework. Using data from 1995/96 for Division I institutions, Sigelman and Wahlbeck (1999) calculate the change in athletic team slots (new opportunities for women, reduced opportunities for men, or an exchange of opportunities of men for women) that would be required to achieve compliance, given current participation rates. Results of OLS regressions show that compliance would require less adjustment "for schools with a smaller proportion of female students, with more financial resources for female athletics, with a smaller athletic program, and without a football team" (p. 518).

Agthe and Billings (2000) test the hypothesis that the financial status of an institution's football team affects the ability of the institution to meet gender equity requirements. Controlling for endowment, total undergraduate enrollment, public/private status, profits (losses) from other men's sports, and conference membership, they find no significant impact of the gap between football's revenues and expenses on the participation gap for Division I-A institutions in 1996/97. One concern in interpreting their results is the potential endogeneity of their football profit/deficit measure. That is, decisions about participation opportunities for women and for men are made jointly. Because these opportunities cost money, expenditures on men's sports, which are included in the football and other sports profits measures, are determined jointly with participation opportunities. As a result, the coefficients of football and other sports profits/deficits in an OLS regression of the participation gap may be biased.

Using a sample of Division I institutions, Stafford (2004) begins with a probit regression of compliance in $2000 / 01$, where compliance is measured as having a female share of athletes within $5 \%$ of the female share of undergraduates. Controlling for formal and informal enforcement 
mechanisms as well as institutional characteristics, she finds that undergraduate enrollment is positively correlated with compliance; in contrast, Southern institutions and schools with a large share of female undergraduates are less likely to be in compliance. Stafford is the only other author to examine changes in the proportionality gap over time. Using OLS regression to explain changes in the proportionality gap for Division I institutions, improvements toward compliance (i.e., shrinkage of the proportionality gap) are associated with greater institutional size, a smaller share of female undergraduates, location in a region other than the South, and the number of NCAA sanctions since 1992.

In summary, existing empirical research has found several institutional characteristics to be negatively correlated with compliance with Title IX's requirements regarding athletic participation: high percentage of undergraduates who are female, small undergraduate enrollment, large total number of athletes, presence of a football program, location in the South, and being a historically Black college or university. Our article adds to this literature in two important ways. First, our data improve upon previous work by including institutions in Divisions I, II, and III and by adjusting for changes in how institutions report athletes over the period; all of the previous research used unadjusted data and only included Division I institutions. As will be shown below, these differences are important and result in a very different portrait of how compliance with Title IX changed over the period. Second, we investigate other characteristics beyond those listed above - most notably, variables that represent the financial situation of the institution - that explain colleges' and universities' degree of compliance with Title IX in 1995/96 and $2001 / 02$.

\section{Description of Title IX Compliance in 1995/96 and 2001/02}

In order to paint a picture of how compliance varies across divisions and across time, we begin by calculating a measure of "substantial proportionality" as outlined by the first prong of the OCR guidelines:

Proportionality gap =

$[(\%$ of undergraduates who are female $)-(\%$ of athletes who are female $)] * 100$

That is, if the proportionality gap is positive and large, then women comprise a smaller share of athletes than of undergraduates; consequently, the institution will not comply with Title IX through the substantial proportionality prong. We adopt a common interpretation of the "substantial proportionality" standard (Farrell, 1995; Sigelman \& 
Wahlbeck, 1999; Zimbalist, 1997) that a differential of no more than 3-5\% signifies compliance. Because most institutions that are out of compliance are found to have a smaller female share of athletes than female share of undergraduates, in this paper we also focus on the following measure ${ }^{1}$ :

Out of compliance (by favoring males) = $\begin{array}{ll}1 & \text { if proportionality gap }>X \\ 0 & \text { if proportionality gap } \geq X\end{array}$

where $\mathrm{X}$ is altematively equal to $3 \%$ or $5 \%$.

We calculate the proportionality gap and the share of our sample out of compliance with the substantial proportionality prong using information contained in reports filed by institutions of higher education as required by the Equity in Athletics Disclosure Act (EADA). We obtained the full EADA reports for 1995/96 from the Women's Sports Foundation (Sabo, 1997) and for 2001/02 from the Department of Education. In addition, we collected supplementary EADA information from the Chronicle of Higher Education's website entitled "Gender Equity in College Sports" (2004).

The EADA questionnaire asks institutions to report the number of male and female athletes participating in each individual sport as well as the total number of male and female athletes. There have been substantial changes in the questionnaire over time, however, that affect the comparability of directly reported data. As discussed in more detail in the Data Appendix, the instructions accompanying the EADA questionnaire and the structure of the data template in the different years result in many institutions reporting unduplicated figures in 1995/96 (that is, an athlete who plays multiple sports is counted only once) and duplicated figures in 2001/02 (that is, an athlete who plays multiple sports is counted once for each sport). The current practice of the Department of Education is to use duplicated figures to calculate substantial proportionality. Because we utilize the full EADA data, including the number of athletes in each specific sport, we calculate duplicated participation figures for both years based on a consistent methodology as discussed in the Data Appendix. This correction required additional data from the NCAA, which graciously provided information on team offerings in $1995 / 96$ and 2001/02. In contrast, previous research relied on unadjusted data, resulting in inconsistent participation figures across time.

Table 1 allows us to examine the importance of these corrections for portraying an accurate picture of Title IX compliance during this period. The table presents compliance measures for the sample of 264 Division 
I institutions that reported data to all three potential sources ${ }^{2}$ t the Chronicle of Higher Education in 1995/96 and 2001/02, the source of unadjusted data used in previous research, and the Women's Sports Foundation in 1995/96 and the Department of Education in 2001/02, the sources of our new adjusted data.

First, note the substantial degree of noncompliance with the substantial proportionality prong among Division I institutions, regardless of the data source. According to the adjusted data, $89-94 \%$ of institutions in $1995 / 96$ and $71-83 \%$ of institutions in 2001/02 do not meet the criterion of substantial proportionality because their female shares of undergraduates are more than 3-5\% larger than their female shares of athletes. Even including the few compliant institutions in the calculation, the average proportionality gap is $14 \%$ in $1995 / 96$ and $10 \%$ in $2001 / 02$. Although these results indicate widespread noncompliance with substantial proportionality during this period, they do reveal improvement over time. These points will be examined in more detail in Table 2.

Table 1 also demonstrates that there are substantial differences between the measures of compliance generated from unadjusted data versus those generated from adjusted data. If one relies on unadjusted data, 1995/96 compliance is underestimated and the average proportionality gap in 1995/96 is overestimated; consequently, improvements in gender equity between 1995/96 and 2001/02 will be overestimated. The magnitude of this inaccuracy is not trivial. Our estimates demonstrate that close to $30 \%$ of the reduction in the proportionality gap in unadjusted data ( 1.6 out of 5.6 percentage points) is eliminated after corrections are made. Therefore, one must exercise caution when examining trends over time using past estimates of compliance that are based on unadjusted data.

TABLE 1

Compliance with Substantial Proportionality For Division I Institutions, Adjusted and Unadjusted Data

\begin{tabular}{lllllll}
\hline \hline & \multicolumn{3}{c}{ Unadjusted Data } & & \multicolumn{3}{c}{ Adjusted Data } \\
\cline { 2 - 7 } Year & $95 / 96$ & $01 / 02$ & Change & $95 / 96$ & $01 / 02$ & Change \\
\hline Mean Proportionality Gap & 15.3 & 9.7 & -5.6 & 13.9 & 9.9 & -4.0 \\
Share with Gap > 3 & $96.2 \%$ & $82.2 \%$ & -14.0 & $94.3 \%$ & $83.0 \%$ & -11.4 \\
Share with Gap > 5 & $92.4 \%$ & $70.1 \%$ & -22.3 & $89.0 \%$ & $70.8 \%$ & -18.2 \\
\hline
\end{tabular}

Notes: "Proportionality gap" is equal to (\% of undergraduates who are female - \% of athletes who are female)*100. The sample consists of the 264 Division I institutions who reported data in $1995 / 96$ to the Chronicle of Higher Education and to the Women's Sports Foundation, and in 2001/02 to the Chronicle of Higher Education and to the Department of Education. The Data Appendix describes the differences between the adjusted and unadjusted data. 
Table 2 presents similar figures for all of the 741 NCAA institutions that reported EADA data to the Women's Sports Foundation in 1995/96 and to the Department of Education in 2001/02. ${ }^{3}$ Unlike all of the past literature reviewed in the previous section, we calculate compliance figures for Division II and III institutions as well as for Division I institutions. Because Division I athletic programs are significantly larger than those from the other divisions in terms of notoriety, facilities, revenue generation, cost, and the degree to which they use athletics as a tool to increase general enrollment, there is no reason to expect compliance with the substantial proportionality prong to be similar across divisions. ${ }^{4}$ In fact, the figures in Table 2 show that compliance differs tremendously by division.

Looking first at the overall figures (not broken down by subdivision) in 1995/96, we see that Division II institutions perform worst in terms of the average proportionality gap: $18 \%$ compared to $14 \%$ in Divisions I and III. In addition, the noncompliance rate is somewhat higher in Division II when allowing for a $5 \%$ leeway (93\% versus $89-90 \%$ in Divisions I and III). By 2001/02, however, the relative equality of Divisions I and III changes because of substantially greater improvement in Division I than in any other division. By 2001/02, the average proportionality gap falls to $10 \%$ for Division I institutions compared with $14 \%$ and $17 \%$ for Divisions II and III, respectively. In addition, the percentage of institutions out of compliance is $10-16 \%$ lower at Division I institutions than at Division II and III schools.

These findings illustrate a second manner in which improvements in compliance with Title IX would be overestimated in past research that focuses solely on Division I: Division I institutions are not representative of NCAA institutions as a whole. For example, looking at the change in the proportionality gap over time, we estimate a reduction of $27 \%(-3.8 \%)$ in Division I versus only $5-8 \%(-0.7 \%$ to $-1.4 \%)$ in Divisions II and III. Similarly, noncompliance rates fall by 4 times as much in Division I relative to Division II $(-17.8 \%$ versus $-4.3 \%)$ and over 9 times as much relative to Division III $(-1.9 \%)$.

Table 2 also presents the mean proportionality gap and noncompliance rates for institutions that offer football versus those who do not offer football; in Division I, only I-AAA does not offer football. As noted by previous authors (Agthe \& Billings, 2000; Rishe, 1999; Sigelman \& Wahlbeck, 1999), the presence of a football team is likely to be extremely important in determining an institution's compliance level due to the large number of male athletes that currently exist on most teams as well as the high cost per athlete in football relative to other sports. For the sample of institutions used in Table 2, the average roster 


\section{TABLE 2}

Compliance with Substantial Proportionality for Division I-III Institutions, Adjusted Data

\begin{tabular}{|c|c|c|c|c|c|c|c|c|c|c|}
\hline \multirow[b]{2}{*}{ Year } & \multirow[t]{2}{*}{ Obs. } & \multicolumn{3}{|c|}{ Mean Proportionality Gap } & \multicolumn{3}{|c|}{ Share with Gap > 3} & \multicolumn{3}{|c|}{ Share with Gap > 5} \\
\hline & & $95 / 96$ & $01 / 02$ & Change & $95 / 96$ & $01 / 02$ & Change & $95 / 96$ & $01 / 02$ & Change \\
\hline All & 741 & 15.2 & 13.1 & -2.1 & $93.4 \%$ & $88.9 \%$ & -4.5 & $90.3 \%$ & $81.9 \%$ & -8.4 \\
\hline Division I & 270 & 14.0 & 10.2 & -3.8 & $94.4 \%$ & $83.3 \%$ & -11.1 & $89.3 \%$ & $71.5 \%$ & -17.8 \\
\hline I-A: BCS & 60 & 11.2 & 6.5 & -4.8 & $91.7 \%$ & $73.3 \%$ & -18.3 & $81.7 \%$ & $58.3 \%$ & 23.3 \\
\hline I-A: Other & 41 & 16.2 & 10.4 & -5.8 & $90.2 \%$ & $78.0 \%$ & -12.2 & $90.2 \%$ & $75.6 \%$ & -14.6 \\
\hline I-AA & 94 & 16.7 & 13.2 & -3.5 & $95.7 \%$ & $90.4 \%$ & -5.3 & $92.6 \%$ & $78.7 \%$ & -13.8 \\
\hline I-AAA & 62 & 11.4 & 9.2 & -2.2 & $98.4 \%$ & $85.5 \%$ & -12.9 & $91.9 \%$ & $71.0 \%$ & -21.0 \\
\hline Division II & 188 & 18.1 & 16.7 & -1.4 & $94.1 \%$ & $93.1 \%$ & -1.1 & $92.6 \%$ & $88.3 \%$ & -4.3 \\
\hline I with football & 106 & 20.3 & 19.8 & -0.5 & $95.3 \%$ & $94.3 \%$ & -0.9 & $94.3 \%$ & $93.4 \%$ & -0.9 \\
\hline II without football & 77 & 15.3 & 12.8 & -2.5 & $93.5 \%$ & $92.2 \%$ & -1.3 & $90.9 \%$ & $83.1 \%$ & -7.8 \\
\hline Division III & 264 & 14.3 & 13.6 & -0.7 & $91.7 \%$ & $92.0 \%$ & 0.4 & $90.2 \%$ & $88.3 \%$ & -1.9 \\
\hline III with football & 162 & 15.4 & 14.9 & -0.6 & $95.1 \%$ & $94.4 \%$ & -0.6 & $93.8 \%$ & $89.5 \%$ & -4.3 \\
\hline III without footbal! & 94 & 12.0 & 11.3 & -0.7 & $85.1 \%$ & $88.3 \%$ & 3.2 & $83.0 \%$ & $86.2 \%$ & 3.2 \\
\hline
\end{tabular}

NoTes: "Proportionality gap" is equal to ( $\%$ of undergraduates who are fernale - \% of athletes who are female)*100. The sample consists of the 741 NCAA institutions who reported data in $1995 / 96$ to the Women's Sports Foundation and in 2001/02 to the Department of Education. All figures use adjusted participation data. The subcategories do not contain the same number of institutions as the larger categories because some instilutions changed division and/or football offerings between $1995 / 96$ and $2001 / 02$. 
size of football teams in 2001/02 is 113 in Division I-A, 95 in Division I-AA, 83 in Division II, and 82 in Division III. No other male or female sports have similar roster sizes. ${ }^{5}$ Much controversy exists over whether the large teams in football are simply an artifact of the favored status of football in most athletic departments or represent the true requirements of the sport. ${ }^{6}$ Regardless of the reason, these large rosters should cause institutions with football teams to fair poorly in recent measurements of substantial proportionality.

Our results indicate that, with the exception of Division I-A schools, offering a football team is associated with a higher proportionality gap and a higher probability of noncompliance with substantial proportionality. For example, the largest average proportionality gap is in Division II with football-approximately $20 \%$ in both years, a difference of $5 \%$ in $1995 / 96$ and $7 \%$ in 2001/02 relative to Division II schools without football. Similarly, in 2001/02 the noncompliance rate among football institutions in Division II is up to $10 \%$ higher than among non-football institutions in Division II. On the other hand, Division I-A institutions demonstrate some of the best compliance figures, especially in 2001/02, because they make the most improvement by far of the institutions in the sample. This is especially true of Division I-A schools in the Bowl Coalition Series (BCS), with the lowest average proportionality gap in $2001 / 02(6.5 \%)$ and the greatest reduction in noncompliance (from $73-82 \%$ of the sample in $1995 / 96$ to $58-73 \%$ of the sample in 2001/02). This difference is not surprising, because as Toma (2003) explains in more detail, the scale of football programs at Division I-A institutions, especially those in the Bowl Championship Series (BCS), is much larger relative to other NCAA schools. Consequently, our results may reflect the importance of revenue-producing men's sports as a subsidy for women's sports in Division I-A, the effect of increased pressure from always being in the spotlight on this issue, or female athletes' greater demand for participation opportunities that results from having superior facilities. ${ }^{7}$ Regardless of the underlying explanation for these results, differences in the relationship between football and compliance with the substantial proportionality prong are one more reason why one should not assume that the experiences of Division I institutions can be generalized to other NCAA institutions.

Regression Methodology and Results

\section{Methodology}

We now turn to regression models in order to investigate which institutional characteristics best explain differences in institutions' compliance 
with Title IX, as measured by the proportionality gap in a given year. In each regression, an institution's degree of compliance with gender equity requirements is a function of the preferences of the institution and its students, the institution's financial ability to provide adequate athletic opportunities for both its male and female students, and structural constraints.

To control for differences in preferences, we include several dichotomous measures of institutional type. First, public institutions (as opposed to private institutions) are more likely to be influenced by their state government; this differential political pressure may affect both overall athletic offerings as well as willingness to comply with Title IX. At the same time, the greater reliance on tuition dollars by private institutions may cause them to alter their athletic offerings to attract additional students. Second, region of the country (South, Midwest, West, and Northeast) is included as a measure of social climate; for example, Rishe (1999) and Stafford (2004) found location in the South to be negatively related to compliance with gender equity. Third, historically Black colleges and universities (HBCUs) may face special challenges in achieving gender equity since their predominantly African-American students historically have participated in only a few sports such as football, basketball, and track. Finally, the selectivity of an institution may affect tastes as well. Highly selective institutions may place less emphasis on athletics relative to academics and may attract students who are more likely to participate in the less traditional sports. For example, the Ivy League is well known for offering a wide range of sports, yet does not offer athletic scholarships to student athletes (Ehrenberg, 2000).

If we hold preferences constant, it is easiest for institutions to comply with Title IX when they are able to generate funds to offer additional women's sports. In particular, institutions with more overall wealth can afford to offer more sports for both men and women, and institutions drawing higher revenues from either men's or women's sports are more able to subsidize additional teams. We focus on measures of overall wealth because revenues generated by athletic departments are poorly measured in available data. Specifically, except in Division I-A, more than $60 \%$ of reported athletic revenues come from institutional support and student fees as opposed to athletic-specific revenues from ticket sales, television contracts, and similar sources (Fulks, 2002a, 2002b). In addition, true athletic revenues may be endogenous if athletic expenditures, which are determined jointly with participation, affect revenue generation. Consequently, we use the following four variables to measure the level of resources available to fund athletic programs: endowment per student, tuition and fees, state appropriations per student, and giving revenues per student. ${ }^{8}$ 
In addition, even among institutions with similar tastes and financial wealth, gender equity compliance may vary due to certain structural issues, relating to the formula that defines the proportionality gap, that make it easier or harder for an institution to comply with Title IX. To begin, because the female share of athletes is compared directly to the female share of undergraduates, institutions where women comprise a large share of the undergraduate student population will have a very difficult time reaching substantial proportionality, especially if the institution also offers a football team at current roster sizes. The results for institutions in our sample support this claim: even allowing leeway of 5\%, 97-98\% of institutions where the female share of undergraduates is greater than $60 \%$ are out of compliance with the substantial proportionality prong (by favoring males) in both $1995 / 96$ and $2001 / 02$. In contrast, among institutions where the female share of undergraduates is less than $40 \%$, the noncompliance rate is only $20 \%$ in $1995 / 96$ and $10 \%$ in 2001/02. In addition to the gender composition, the size of an institution's enrollment is likely to influence the institution's ability to comply. Larger institutions can enroll numerous recruited athletes while still leaving a large quantity of enrollment slots available for other students; they also have access to a larger pool of students from which they can draw walk-ons.

Structural constraints are also imposed by an institution's division and conference affiliation. As discussed earlier, each NCAA division has requirements for the number of sports offered for both men and women as well as rules regarding financial aid awards. Therefore, an institution's division membership is likely to influence the number of male and female athletes and, subsequently, measured compliance with substantial proportionality. In addition, conference affiliation is expected to be important because an institution may be less likely to offer a sport if other teams in its conference do not offer the sport and, consequently, do not offer the institution convenient opponents to schedule. Finally, as discussed above, the presence of a football team may be extremely important in determining an institution's compliance level because of the large rosters currently existing in the sport as well as the high cost per athlete in this sport.

The regressions below are estimated both with and without controlling for division, conference, and football because these variables may be endogenous. On the one hand, the presence of a football team or the institution's division or conference affiliation is determined jointly with the presence and size of other athletic teams, including women's teams. On the other hand, many would argue that these three elements are exogenously determined by the history of the institution. That is, at some 
point in the past, each institution made the decision whether or not to field a football team or which division or conference to join, and these decisions are not likely to change regardless of Title IX or other pressures. If the former story better reflects reality than the latter story, then one should interpret with caution the results for regressions that control for division, conference, and football due to possible endogeneity.

In our cross-section regressions, we enter the independent variables in blocks to see how the results for institutional type change as controls are added and to recognize the possible endogeneity of division, football, and conference variables. Below is the final specification that includes all variables, run separately for $1995 / 96$ and $2001 / 02$ :

$$
Y_{i}=\alpha+\beta P_{i}+\gamma F_{i}+\phi E_{i}+\delta D_{i}+\psi C_{i}+\mu_{i}
$$

where $Y_{i}$ represents the proportionality gap for institution $i ; P_{i}$ is a vector of variables describing preferences of the institution and its students: institutional control (private versus public), Census region (Northeast, Midwest, South, versus West), indicator for historically Black college or university (HBCU), and Barron's Profiles of American Colleges selectivity group indicators (selective, more selective, highly/most selective, versus non/less selective); $F_{i}$ is a vector of variables measuring institution $i$ 's financial wealth (endowment per student, tuition and fee level, state appropriations per student, and giving dollars per student); $E_{i}$ is a vector of variables measuring the enrollment of institution $i$ (percentage of undergraduates who are female and FTE undergraduate enrollment); $D_{i}$ is a vector of indicator variables representing division membership (Divisions II or III versus Division I) and football offerings of institution $i$; $C_{i}$ is a vector of variables representing the institution $i$ 's conference; $\alpha$, $\beta, \gamma, \phi, \delta$, and $\psi$ are vectors of coefficients; and $\mu_{i}$ is an error term. ${ }^{9}$ Finally, we estimate first-difference regressions that explore changes in the proportionality gap between $1995 / 96$ and $2001 / 02$.

The data measuring these variables are culled from various sources. Information on institutions' demographic characteristics, enrollment, and financial wealth are collected from the Integrated Postsecondary Education Data System (IPEDS). Data on overall giving (donations) are from the Council for Aid to Education's Voluntary Support of Education Survey. A survey conducted by the National Association of College and University Business Officers (NACUBO) yields information on institution's endowment assets. Selectivity indicators are from the 1999 edition of Barron's Profiles of American Colleges. Conference and division information are from the NCAA. The EADA survey provides athletic data as well as the female share of undergraduates. 
Our regression sample is slightly smaller than our descriptive sample (presented in Table 2) for two reasons. First, 23 institutions are missing data on their selectivity level or tuition and fees, and are thus dropped from the sample. ${ }^{10}$ Second, we exclude from the regressions 22 institutions in 1995/96 and 34 institutions in 2001/02 who have a negative proportionality gap-that is, the female share of athletes is in fact greater than the female share of undergraduates-because the effect of many of the independent variables are likely to be different for these institutions. ${ }^{11}$ Because of the sample construction, all regression coefficients should be interpreted as the marginal effect of the explanatory variable given that the institution's proportionality gap is positive; that is, one should not use our results to predict the behavior of institutions whose proportionality gaps are negative. Table 3 presents descriptive statistics for all variables that are used in the regressions for the final sample of 696 institutions in 1995/96 and 684 institutions in 2001/02. ${ }^{12}$

TABLE 3

Descriptive Statistics of Regression Variables

\begin{tabular}{lrrrr}
\hline & \multicolumn{2}{c}{ 1995 Dala } & \multicolumn{2}{c}{ 2001 Data } \\
\cline { 2 - 5 } Variable & Mean & Std. Dev, & Mean & Sid. Dev. \\
\hline & 16.012 & 7.745 & 14.090 & 7.984 \\
Proportionality Gap & 0.497 & & 0.497 & \\
Private & 0.284 & & 0.288 & \\
Northeast & 0.244 & & 0.238 & \\
Midwest & 0.351 & & 0.355 & \\
South & 0.040 & & 0.041 & \\
HBCU & 0.424 & & 0.420 & \\
Competitive & 0.220 & & 0.221 & \\
More Selective & 0.126 & & 0.127 & \\
Highly/Most Selective & 26.129 & 53.716 & 39.649 & 87.130 \\
Endowment Assets per WFTE & 9.860 & 7.430 & 10.851 & 8.095 \\
Tuition \& Fees & 3.003 & 3.352 & 3.021 & 3.343 \\
State Appropriations per WFTE & 2.667 & 3.408 & 3.451 & 4.385 \\
Giving Doilars per WFTE & 54.723 & 7.149 & 56.314 & 6.853 \\
\% Female Undergrads & 5.832 & 5.697 & 6.209 & 6.165 \\
FTE Undergrad Enrollment & 0.274 & & 0.257 & \\
Division II & 0.352 & & 0.363 & \\
Division lII & 0.659 & & 0.673 & \\
Football & 696 & & 684 & \\
Number of Observations & & & & \\
\hline
\end{tabular}

NoTES: WFTE stands for weighted full-time equivalency enrollment, in which graduate students are weighted by a factor of two. Endowment, Tuition \& Fees, State Appropriations, Giving Dollars, and FTE Undergrad Enrollment are all measured in 1.000 s. Endowment Assets figures are based on 548 and 544 observations in $1995 / 96$ and $2001 / 02$, respectively. Giving dollars are based on 495 and 482 observations in $1995 / 96$ and 2001/02, respectively. All dollar figures are in 2001 dollars. 


\section{Results}

Tables 4 and 5 present regression results for $1995 / 96$ and 2001/02, respectively. For both tables, Columns 1-4 report models in which independent variables are added in successive blocks reflecting preferences, finances, enrollment, and division/football offerings. Column 5 replaces division controls with conference-specific fixed effects. Recall that the models that include division, conference, or football should be interpreted with caution due to the potential endogeneity of these variables.

To begin, consider the variables representing institutional and student preferences. In nearly all specifications, private institutions have significantly larger proportionality gaps than public institutions have, possibly reflecting private institutions' use of athletics to increase male enrollment and their tuition dollars or public institutions' response to pressures or incentives from their state governments. With respect to regional differences, the proportionality gap is larger in Midwestern and Southern institutions; this difference is bigger in 2001/02 than in 1995/96, suggesting that Western schools (the excluded category) improved compliance relative to other institutions. The results for historically Black colleges and universities are interesting. In both years, the coefficient of HBCU is positive and statistically significant in models 1 and 2, becomes nearly zero and insignificant in model 3 (when enrollment figures are added), and turns negative and significant in model 4 (when controlling for division and football). This result is easily explained: HBCUs in our sample have much higher shares of female undergraduates, are more likely to be in Division II, and are more likely to offer football than are non-HBCUs. Finally, it appears that institutional selectivity is positively related to compliance; that is, as selectivity increases, the proportionality gap decreases, especially in 2001/02. Not surprisingly, the effect diminishes as controls are added.

Turning now to financial measures, overall our results conform to the expected wealth effect: schools with access to greater financial resources have smaller proportionality gaps, all else equal. However, this impact lessens over time. On the one hand, this is consistent with the possibility that compliance, once a luxury only afforded by rich institutions, is becoming more of a necessity regardless of institutional wealth. On the other hand, this result is surprising since most institutions have improved compliance over time through the expensive route of adding women's teams and/or participants as opposed to cutting men's athletics (Anderson \& Cheslock, 2004; Cheslock \& Anderson, 2004). Among the financial variables, the results vary by the source of funds. For example, endowment per student has no significant effect on the proportionality 
TABLE 4

Determinants of Proportionality Gap, OLS (1995)

\begin{tabular}{|c|c|c|c|c|c|}
\hline Independent Variable & (1) & (2) & (3) & (4) & (5) \\
\hline Private & $\begin{array}{c}0.194 \\
(0.579)\end{array}$ & $\begin{array}{r}2.889 * \\
(1.631)\end{array}$ & $\begin{array}{c}3.109 * * \\
(1.446)\end{array}$ & $\begin{array}{l}5.682^{* * * *} \\
(1.197)\end{array}$ & $\begin{array}{l}4.415^{* * *} \\
(1.497)\end{array}$ \\
\hline Northeast & $\begin{array}{c}-0.048 \\
(0.952)\end{array}$ & $\begin{array}{c}0.284 \\
(0.960)\end{array}$ & $\begin{array}{c}-0.671 \\
(0.856)\end{array}$ & $\begin{array}{c}-0.013 \\
(0.712)\end{array}$ & $\begin{array}{l}4.118^{* *} \\
(1.919)\end{array}$ \\
\hline Midwest & $\begin{array}{l}2.549^{* * *} \\
(0.964)\end{array}$ & $\begin{array}{l}2.695^{* * * *} \\
(0.949)\end{array}$ & $\begin{array}{l}2.797 * * * \\
(0.839)\end{array}$ & $\begin{array}{l}1.684^{* *} \\
(0.697)\end{array}$ & $\begin{array}{l}4.363^{* *} \\
(1.717)\end{array}$ \\
\hline South & $\begin{array}{l}3.568^{* * * *} \\
(0.924)\end{array}$ & $\begin{array}{l}2.994^{* * * *} \\
(0.924)\end{array}$ & $\begin{array}{l}2.521^{* * * *} \\
(0.822)\end{array}$ & $\begin{array}{l}3.306^{* * *} \\
(0.682)\end{array}$ & $\begin{array}{l}5.934^{* * *} \\
(1.697)\end{array}$ \\
\hline $\mathrm{HBCU}$ & $\begin{array}{l}3.064^{* *} \\
(1.462)\end{array}$ & $\begin{array}{c}2.453^{*} \\
(1.462)\end{array}$ & $\begin{array}{c}0.450 \\
(1.301)\end{array}$ & $\begin{array}{l}-2.919 * * * \\
(1.091)\end{array}$ & $\begin{array}{c}-1.811 \\
(2.367)\end{array}$ \\
\hline Competitive & $\begin{array}{c}-0.933 \\
(0.714)\end{array}$ & $\begin{array}{c}-0.120 \\
(0.717)\end{array}$ & $\begin{array}{c}-0.423 \\
(0.634)\end{array}$ & $\begin{array}{c}-0.839 \\
(0.526)\end{array}$ & $\begin{array}{c}-0.558 \\
(0.558)\end{array}$ \\
\hline More Selective & $\begin{array}{l}-3.067^{* * *} \\
(0.840)\end{array}$ & $\begin{array}{c}-\nmid .058 \\
(0.902)\end{array}$ & $\begin{array}{c}-1.164 \\
(0.806)\end{array}$ & $\begin{array}{l}-1.471^{* *} \\
(0.665)\end{array}$ & $\begin{array}{c}-1.182 \\
(0.722)\end{array}$ \\
\hline Highly/Most Selective & $\begin{array}{l}-6.864 * * * * \\
(1.007)\end{array}$ & $\begin{array}{l}-2.381^{* *} \\
(1.314)\end{array}$ & $\begin{array}{c}-0.758 \\
(1.204)\end{array}$ & $\begin{array}{c}-1.131 \\
(0.989)\end{array}$ & $\begin{array}{c}-0.942 \\
(1.085)\end{array}$ \\
\hline Endowment Assets per WFTE & & $\begin{array}{c}0.007 \\
(0.009)\end{array}$ & $\begin{array}{c}0.011 \\
(0.008)\end{array}$ & $\begin{array}{c}0.008 \\
(0.007)\end{array}$ & $\begin{array}{c}0.010 \\
(0.007)\end{array}$ \\
\hline Tuition \& Fees & & $\begin{array}{l}-0.371 * * * \\
(0.109)\end{array}$ & $\begin{array}{l}-0.353 * * * \\
(0.097)\end{array}$ & $\begin{array}{c}-0.371 * * * \\
(0.081)\end{array}$ & $\begin{array}{l}-0.296 * * * \\
(0.103)\end{array}$ \\
\hline State Appropriations per WFTE & & $\begin{array}{c}-0.344^{*} \\
(0.188)\end{array}$ & $\begin{array}{c}0.073 \\
(0.170)\end{array}$ & $\begin{array}{l}0.276^{* *} \\
(0.141)\end{array}$ & $\begin{array}{l}0.308^{* * *} \\
(0.156)\end{array}$ \\
\hline Giving Dollars per WFTE & & $\begin{array}{c}-0.290^{*} \\
(0.152)\end{array}$ & $\begin{array}{c}-0.188 \\
(0.135)\end{array}$ & $\begin{array}{c}-0.288^{* * *} \\
(0.111)\end{array}$ & $\begin{array}{c}-0.279 * * \\
(0.121)\end{array}$ \\
\hline$\%$ Female Undergrads & & & $\begin{array}{l}0.455^{* * *} \\
(0.036)\end{array}$ & $\begin{array}{l}0.661^{* * * *} \\
(0.031)\end{array}$ & $\begin{array}{l}0.669 * * * \\
(0.034)\end{array}$ \\
\hline FTE Undergrad Enrollment & & & $\begin{array}{l}-0.182^{* * * *} \\
(0.059)\end{array}$ & $\begin{array}{l}-0.188^{* * *} \\
(0.056)\end{array}$ & $\begin{array}{c}-0.132^{*} \\
(0.074)\end{array}$ \\
\hline Division II & & & & $\begin{array}{l}1.810^{* * * *} \\
(0.589)\end{array}$ & \\
\hline Division IJI & & & & $\begin{array}{c}0.711 \\
(0.592)\end{array}$ & \\
\hline Footbal! & & & & $\begin{array}{l}8.524^{* * * * *} \\
(0.472)\end{array}$ & $\begin{array}{l}8.658^{* * *} \\
(0.554)\end{array}$ \\
\hline Conference Effects & No & No & No & No & Yes \\
\hline Adjusted R-squared & 0.148 & 0.183 & 0.363 & 0.571 & 0.540 \\
\hline
\end{tabular}

NOTEs: $\mathrm{N}=6 \%$. Dollar figures are measured in $\$ 1,000$ (real 200/dollars). FTE enrollment is measured in 1,000 s. All models include an intercepl. In model (5), estimated using fixed-effects regression, we report the within R-squared. ***,**, and * represent significance at the 1,5 , and $10 \%$ levels, respectively.

gap, whereas tuition and fees are strongly negatively related to the proportionality gap in all specifications. Although consistently inversely related to the proportionality gap in 1995/96, the effect of giving is small and insignificant in 2001/02. Finally, greater state appropriations 
TABLE 5

Determinants of Proportionality Gap, OLS (2001)

\begin{tabular}{|c|c|c|c|c|c|}
\hline Independent Variable & (1) & (2) & (3) & (4) & (5) \\
\hline Private & $\begin{array}{l}2.224 * * * * \\
(0.590)\end{array}$ & $\begin{array}{c}3.297^{*} \\
(1.799)\end{array}$ & $\begin{array}{c}2.610 \\
(1.599)\end{array}$ & $\begin{array}{l}4.382^{* * *} \\
(1.306)\end{array}$ & $\begin{array}{l}3.363^{* *} \\
(1.636)\end{array}$ \\
\hline Northeast & $\begin{array}{c}1.562 \\
(0.971)\end{array}$ & $\begin{array}{c}1.808^{*} \\
(0.973)\end{array}$ & $\begin{array}{c}0.707 \\
(0.869)\end{array}$ & $\begin{array}{c}0.875 \\
(0.716)\end{array}$ & $\begin{array}{l}4.690^{* *} \\
(1.874)\end{array}$ \\
\hline Midwest & $\begin{array}{l}3.971^{* * * *} \\
(0.992)\end{array}$ & $\begin{array}{l}4.190^{* * *} \\
(0.968)\end{array}$ & $\begin{array}{l}4.031^{* * * *} \\
(0.858)\end{array}$ & $\begin{array}{l}2.247^{* * *} \\
(0.707)\end{array}$ & $\begin{array}{l}4.860^{* * *} \\
(1.625)\end{array}$ \\
\hline South & $\begin{array}{l}4.140^{* * *} \\
(0.944)\end{array}$ & $\begin{array}{l}3.642^{* * * *} \\
(0.927)\end{array}$ & $\begin{array}{l}3.185^{* * * *} \\
(0.825)\end{array}$ & $\begin{array}{l}3.459 * * * \\
(0.675)\end{array}$ & $\begin{array}{l}4.962^{* * *} \\
(1.559)\end{array}$ \\
\hline $\mathrm{HBCU}$ & $\begin{array}{c}3.769^{* *} \\
(1.474)\end{array}$ & $\begin{array}{l}3.041 * * \\
(1.462)\end{array}$ & $\begin{array}{c}0.440 \\
(1.307)\end{array}$ & $\begin{array}{l}-2.276^{* *} \\
(1.080)\end{array}$ & $\begin{array}{c}1.227 \\
(2.367)\end{array}$ \\
\hline Competitive & $\begin{array}{c}-1.198^{*} \\
(0.725)\end{array}$ & $\begin{array}{c}-0.330 \\
(0.719)\end{array}$ & $\begin{array}{c}-0.665 \\
(0.640)\end{array}$ & $\begin{array}{l}-1.160^{* *} \\
(0.523)\end{array}$ & $\begin{array}{c}-0.961^{*} \\
(0.539)\end{array}$ \\
\hline More Selective & $\begin{array}{c}-3.796^{* * *} \\
(0.854)\end{array}$ & $\begin{array}{c}-1.375 \\
(0.915)\end{array}$ & $\begin{array}{c}-1.453^{*} \\
(0.823)\end{array}$ & $\begin{array}{l}-1.682^{* *} \\
(0.670)\end{array}$ & $\begin{array}{l}-1.709^{* * *} \\
(0.696)\end{array}$ \\
\hline Highly/Most Selective & $\begin{array}{l}-9.075^{* * *} \\
(1.023)\end{array}$ & $\begin{array}{c}-4.415^{* * *} \\
(1.362)\end{array}$ & $\begin{array}{l}-2.587^{* *} \\
(1.233)\end{array}$ & $\begin{array}{l}-2.741^{* * *} \\
(0.999)\end{array}$ & $\begin{array}{l}-2.958^{* * * *} \\
(1.054)\end{array}$ \\
\hline Endowment Assets per WFTE & & $\begin{array}{c}0.002 \\
(0.006)\end{array}$ & $\begin{array}{c}0.002 \\
(0.005)\end{array}$ & $\begin{array}{c}0.000 \\
(0.004)\end{array}$ & $\begin{array}{l}-0.001 \\
(0.004)\end{array}$ \\
\hline Tuition \& Fees & & $\begin{array}{l}-0.281 * * \\
(0.113)\end{array}$ & $\begin{array}{l}-0.279^{* * *} \\
(0.100)\end{array}$ & $\begin{array}{l}-0.296^{* * *} \\
(0.083)\end{array}$ & $\begin{array}{c}-0.200^{* *} \\
(0.102)\end{array}$ \\
\hline State Appropriations per WFTE & & $\begin{array}{c}-0.462 * * \\
(0.196)\end{array}$ & $\begin{array}{c}-0.040 \\
(0.176)\end{array}$ & $\begin{array}{c}0.095 \\
(0.143)\end{array}$ & $\begin{array}{c}0.127 \\
(0.155)\end{array}$ \\
\hline Giving Dollars per WFTE & & $\begin{array}{c}-0.178 \\
(0.127)\end{array}$ & $\begin{array}{c}-0.035 \\
(0.113)\end{array}$ & $\begin{array}{c}-0.063 \\
(0.093)\end{array}$ & $\begin{array}{c}-0.071 \\
(0.095)\end{array}$ \\
\hline$\%$ Female Undergrads & & & $\begin{array}{l}0.411^{* * *} \\
(0.038)\end{array}$ & $\begin{array}{l}0.644^{* * * *} \\
(0.033)\end{array}$ & $\begin{array}{l}0.674^{* * *} \\
(0.034)\end{array}$ \\
\hline FTE Undergrad Enroliment & & & $\begin{array}{l}-0.343^{* * *} \\
(0.054)\end{array}$ & $\begin{array}{l}-0.274^{* * *} \\
(0.051)\end{array}$ & $\begin{array}{c}-0.185^{* * *} \\
(0.066)\end{array}$ \\
\hline Division II & & & & $\begin{array}{l}2.384^{* * *} \\
(0.594)\end{array}$ & \\
\hline Division III & & & & $\begin{array}{l}2.344^{* * * *} \\
(0.578)\end{array}$ & \\
\hline Football & & & & $\begin{array}{l}8.647^{* * *} \\
(0.474)\end{array}$ & $\begin{array}{l}8.483^{* * *} \\
(0.543)\end{array}$ \\
\hline Conference Effects & No & No & No & No & Yes \\
\hline Adjusted R-squared & 0.185 & 0.231 & 0.399 & 0.605 & 0.556 \\
\hline
\end{tabular}

NotEs: $\mathrm{N}=684$. Dollar figures are measured in $\$ 1,000$ (real 2001dollars). FTE enrollment is measured in 1,000s. All models include an intercept. In model (5), estimated using fixed-effects regression, we report the within Rsquared. ${ }^{* * *},{ }^{* *}$, and * represent significance at the 1,5 , and $10 \%$ levels, respectively.

contribute to smaller proportionality gaps, all else equal, except when controls for structural constraints are added (models 3-5).

Moving on to structural constraints, we first add two variables relating to enrollment. As expected, institutions where females comprise a large share of the undergraduate student population have significantly larger 
proportionality gaps; this effect is similar in size in all models for both years. For example, if the female share of the undergraduate population increases by $10 \%$, then the proportionality gap grows by approximately $4 \%-4.5 \%$ (see column 3). This illustrates the easier path to compliance for institutions like military academies and institutes of technology compared to schools that attract a larger share of women. In addition, the larger the FTE undergraduate enrollment, the smaller the proportionality gap, all else equal. This result may reflect the ability of large institutions to increase women's athletics because a big student body likely contains more interested walk-ons and also allows the institution to admit a large number of recruited athletes while still leaving many enrollment slots for non-athletes. Further, the effect of school size grows in magnitude over the period, suggesting that large institutions made greater progress toward gender equity relative to smaller institutions.

Finally, we control for structural constraints due to football teams and division (column 4) or conference (column 5) membership. Consistent with our findings in Table 2, membership in Division II or III is associated with a larger proportionality gap relative to Division I (the excluded category), and this difference is more pronounced by 2001/02 because Division I makes the greatest gains in compliance. However, the regression results show that some of the overall difference between Divisions I and II is explained by differences in institutional characteristics (that is, the coefficient on the indicator for Division II is smaller than the difference in average proportionality gaps). All else equal, the presence of a football team is associated with a proportionality gap that is larger by about $8.5 \%$; this effect is consistent across all specifications and across time. We also estimate a model that allows the effect of football to vary across divisions. Interestingly, the results are identical across divisions in 1995, but show some minor differences in $2001 .{ }^{13}$ Comparing these results to Table 2 indicates that the presence of a football team increases the proportionality gap even more after controls are added within a regression.

To this point, we have not taken advantage of the panel nature of our data set. We could estimate a first-difference regression in which the change in the proportionality gap over the period is regressed on the change in the independent variables that are time-variant. However, such a model assumes stability over time in the regression coefficients, a questionable assumption given the increasing penalty of noncompliance with Title IX over the period. In fact, the above discussion of Tables 4 and 5 illustrates several institutional characteristics that become more or less important determinants of the proportionality gap between 1995/96 and 2001/02, and a formal Chow test rejects the null hypothesis of no 
structural change. Therefore, the assumptions required under the firstdifference model are not met, and estimates should be viewed with caution. That said, the first-difference results (available upon request) are quite consistent with the cross-section models reported above, especially with respect to the female share of undergraduates, division membership, and football status. ${ }^{14}$

\section{Conclusion}

This article describes the level of noncompliance with Title IX, as measured by the proportionality gap, between $1995 / 96$ and 2001/02, and then investigates why some institutions perform better than others do on this measure of gender equity. Several conclusions and policy implications are worthy of note. To begin, our descriptive results show that noncompliance with the substantial proportionality prong (in terms of women being underrepresented among athletes) decreases from about $90-93 \%$ of the sample in $1995 / 96$ to about $82-89 \%$ of the sample in $2001 / 02$, with an average gap of $13 \%$ in $2001 / 02$. Because, as discussed earlier in the paper, substantial proportionality is the only long-term "safe harbor" for institutions of higher education given the current interpretation of Title IX, the vast majority of institutions will be vulnerable to lawsuits seeking greater gender equity unless future increases in women's athletics occur. This is especially true because improvements in gender equity are smaller than previously thought, once adjustments are made to ensure a consistent reporting methodology (based on duplicated counts of athletes) for a more complete sample derived from institutions in all NCAA divisions (rather than just Division I). The latter point is important because Division I schools, especially those in I-A, show considerably more progress than NCAA institutions in Divisions II and III show. The greatest gender inequity in terms of participation currently occurs in the smaller NCAA divisions who have received much less press coverage. ${ }^{15}$

These findings are important because the speed by which institutions are improving gender equity in athletics is a major point of disagreement among proponents and opponents of the current implementation of Title IX. For example, other data on gains in gender equity were interpreted as "not worth getting excited about," "steady progress," and "tremendous progress" by a women's athletic director, the executive director of the NCAA, and the executive director of the American Football Coaches Association, respectively (Naughton, 1998). Because our findings demonstrate much slower improvement in gender equity than previously thought, claims of "tremendous progress" are harder to support. 
Our regression results reveal several interesting findings that call for additional research. First, we find that, all else equal, institutions in the South and Midwest fare worse than those in the Northeast and West in terms of compliance with substantial proportionality. Future work could investigate the source of these regional differences. In addition, the regression results demonstrate that lower selectivity, less financial wealth, a larger female share of undergraduates, and a smaller undergraduate student body are all associated with a large proportionality gap, all else equal. Institutions with several of these characteristics in combination may face considerable difficulty reaching compliance with substantial proportionality. One example is small and less wealthy institutions with an extremely high female share of undergraduates. After offering the minimum number of men's sports required by their NCAA division, these institutions may not have the available resources or sufficient interest and ability among female students to reach substantial proportionality as currently defined. Future research should investigate the degree to which these institutions can reasonably balance the requirements of Title IX and their NCAA division, given their financial and enrollment situations.

That said, although the problem described above may be an issue for a few schools, our data suggest that this type of technicality is not driving the widespread noncompliance with the substantial proportionality prong of Title IX. For example, among institutions where females comprise $48-52 \%$ of the undergraduate student body, the noncompliance rate (favoring males) is still as high as $68-83 \%$ in $2001 / 02$. Clearly, if one accepts substantial proportionality as an appropriate measure of gender equity in intercollegiate athletics, institutions have a long way to go in the years to come. 


\section{DATA APPENDIX}

This section discusses our adjustment of the athletic participation data reported according to the Equity in Athletics Disclosure Act (EADA). The EADA requires institutions to list the number of athletes participating in each of the different sports, separately by gender. To ensure that we have data that are correct and comparable over time, we made the following adjustments: identified the team listed in the "other sport" category using information from the websites of each institution's athletic department; dropped participants listed as cheerleaders, consistent with Department of Education policy during the period of study; corrected for missing data in the 2001/02 public data set released by the Department of Education using the Office of Postsecondary Education's gender equity website; and assigned $1995 / 96$ athletes on coed teams to specific genders using the sport-specific gender breakdown in later years.

One additional adjustment is the primary cause of the differences between adjusted and unadjusted participation figures found in Table 1. Due to variation in the 1995/96 and 2001/02 reporting templates, institutions were more likely to report unduplicated figures (in which multi-sport athletes are counted only once) in $1995 / 96$ and duplicated figures (in which a multi-sport athlete is counted once for each team on which he/she participates) in 2001/02. This problem mostly occurs for athletes participating in cross-country, indoor track and fjeld, and outdoor track and field.

Comparing the total number of athletes in these three sports in our data with figures reported by the NCAA (Bray, 2003) demonstrates that there are reporting differences over time. Bray (2003) finds that, from $1995 / 96$ to $2001 / 02$, the average institution added 4.5 women in these sports while eliminating 1.8 men. Meanwhile our unadjusted data suggest that the average institution added 17.7 men and 21.0 women over this same period. These differences are due to the reporting of undupticated data in 1995/96 that leads to severe underestimates of the number of participation slots in these sports.

To eliminate this problem, we adjusted the data for the cross-country, indoor track and field, and outdoor track and field teams assuming that duplicated counts were reported in 1995/96 and unduplicated counts were reported in $2001 / 02$. Due to the complexity of the reporting differences over time, the details of this adjustment procecture are left to a longer data appendix available upon request. After the adjustment, we find that the average institution added 4.7 women in these three sports and eliminated 1.9 men, which is very close to the above figur s from the NCAA.

\section{Endnotes}

${ }^{1}$ Very few institutions-approximately $2.5 \%$ of the sample in both $1995 / 96$ and $2001 / 02$ - fail to meet the substantial proportionality standard because they have a smaller share of male athletes than male undergraduates. These institutions are mostly military or technology schools that have a very small share of female undergraduates.

${ }^{2}$ We do not include in our sample either single-sex institutions that draw over $90 \%$ of their undergraduates from only one gender or multi-institution athletic departments (Pomona-Pitzer and Claremont-Mudd Scripps).

${ }^{3}$ Our sample consists of slightly more than $80 \%$ of Division I institutions and close to $65 \%$ of all Division II and III institutions.

${ }^{4}$ There are additional differences by division. For example, the minimum number of teams required for both men and women is seven for Division I, four for Division II, and five for Division III. Another major difference is in financial aid awards related to athletic ability. Division I has a minimum financial aid award requirement, Division II allows financial aid but requires no minimum, and Division III does not allow athletic financial aid.

5Rowing, which averages 52 athletes per women's teams and 40 athletes per men's teams in $2001 / 02$, is the next largest sport for both genders. 


\section{The Journal of Higher Education}

6For arguments supporting the former claim, see U.S. Department of Education (2002) for Andrew Zimbalist's testimony before the Commission on Opportunity in Athletics. Blum (1993) contains arguments supporting the latter claim. Much of the disagreement focuses on whether the collegiate football game is similar to the professional game, in which teams have only 53 players on each roster.

${ }^{7}$ Some evidence exists regarding the extent to which football teams subsidize women sports, but it is complicated by several concerns regarding how revenues and expenditures of football programs are measured. Borland, Goff, and Pulsinelli (1992) claim that these issues lead to underestimates of football's profitability, while Zimbalist (1999) believes they lead to overestimates. Using the best available data, Leeds, Suris, and Durkin (2004) find that only programs generating the highest football profits actually subsidize women's athletics; in simulations, this amounted to only nine institutions out of a sample of 201 Division I-A and I-AA schools.

8"Per student" revenue figures are divided by a measure of full-time equivalent enrollment that weights graduate students by two to reflect the higher cost of their education (Bowen, 1980; Brinkman, 1990; O'Neill, 1971). All revenue figures are adjusted to 2001 dollars using the Higher Education Price Index (HEPI). It is important to note that state appropriation dollars cannot be used for intercollegiate athletics in some states; in these states, increased levels of state appropriations can only reach athletics by releasing other unrestricted funds that would otherwise be spent elsewhere at the institution.

${ }^{9}$ Due to the large number of conferences, the final model in each year is estimated using fixed-effects; this method is equivalent to including an indicator variable for each conference in the regression. Division and conference are not included in the same regression because they are perfectly collinear.

${ }^{10}$ To preserve sample size, we set to zero any missing values for endowment or overall giving and include in the regression indicator variables for missing information on these variables. We use this method because approximately 200 institutions are missing data for at least one of these two variables. Our results are not sensitive to our treatment of missing data. Regressions estimated with the smaller sample of institutions missing no data as well as regressions estimated for the full sample of institutions excluding the endowment and giving variables from the analysis generate qualitatively similar results to those reported in this article. These results are available from the authors upon request.

"A Chow predictive test (Greene, 1997, p. 353) rejects the null hypothesis that the regression coefficients are the same for institutions with a positive proportionality gap and institutions with a negative proportionality gap. Despite this finding, results estimated for the full sample are qualitatively similar to those reported here. A total of 42 schools had a negative proportionality gap in $1995 / 96$ or $2001 / 02$. Of those 42,14 had a negative gap in both years, 8 moved from a negative gap to a positive gap over the period, and 20 moved from a positive gap to a negative gap.

${ }^{12}$ We also estimate all regressions using a consistent sample of 676 institutions with a positive proportionality gap in both years; all results are qualitatively similar to those reported in the text.

${ }^{13}$ In 1995, the coefficients on interaction terms between the football indicator and division indicator are 8.62 for Division I, 8.32 for Division II, and 8.63 for Division III. In 2001, the analogous coefficients are 7.21 for Division I, 10.85 for Division II, and 8.20 for Division III.

${ }^{14}$ The results for the financial variables differ from Tables 4 and 5 once time effects are added to control for omitted variables that fluctuate consistently across institutions between 1995/96 and 2001/02; specifically, the coefficients of tuition and fees and giving become statistically insignificant and turn positive. In all first-difference specifications, undergraduate enrollment continues to be negative and statistically significant, but the size of its coefficient is much larger than in Tables 4 and 5.

${ }^{15}$ Suggs (2004) is one of the few authors that examines institutions outside of Division I. He focuses on Divisions II and III, as well as non-NCAA institutions, and finds substantially larger proportionality gaps than at Division I schools. 


\section{References}

Agthe, D., \& Billings, R. B. (2000). The role of football profits in meeting Title IX gender equity regulations and policy. Journal of Sports Management, 14, 28-40.

Anderson, D. J., \& Cheslock, J. J. (2004). Institutional strategies to achieve gender equity in intercollegiate athletics: Does Title IX harm male athletes? American Economic Review, 94(2), 307-311.

Barron's Profiles of American Colleges. (1999). USA: Barron's.

Blum, D. A. (1993, July 28). Football coaches see little cheer in the future. The Chronicle of Higher Education. Retrieved October 6, 2005, from http://chronicle.com/chedata/articles, dir/articles-39,dir/issue-47,dir/47a03201.htm.

Borland, M. V., Goff, B. L., \& Pulsinelli, R. W. (1992). College athletics: Financial burden or boon? In G. W. Scully (Ed,), Advances in the economics of sport (Vol. 1, pp. 215-235). Greenwich, CT: JAI Press.

Bowen, H. R. (1980). The costs of higher education. San Francisco: Jossey-Bass.

Bray, C. (2003). 1981-82-2001-02 NCAA sports sponsorship and participation rates report. Indianapolis, IN: National Collegiate Athletic Association.

Brinkman, P. T. (1990). Higher education cost functions. In S. A. Hoenack \& E. L. Collins (Eds.), The economics of American universities: Management, operations, and fiscal environment (pp. 107-128). Albany, NY: State University of New York Press.

Carroll, K., \& Humphreys, B. (2000). Nonprofit decision making and social regulation: The intended and unintended consequences of Title IX. Journal of Economic Behavior and Organization, 43(3), 359-76.

Cheslock, J. J., \& Anderson, D. J. (2004, May). Changes in men's and women's athletics: The role of Title IX and the arms race. Unpublished manuscript, University of Arizona.

Chronicle of Higher Education. (2004). Gender Equity in College Sports. Retrieved from http:/chronicle.com/stats/genderequity/.

Ehrenberg, R. G. (2000). Tuition rising. Boston: Harvard University Press.

Farrell, R. C. (1995). Title IX or college football? Houston Law Review, 32, 993-1058.

Fulks, D. (2002a). Revenues and expenses of Division I and II intercollegiate athletics programs: Financial trends and relationships. Indianapolis, IN: National Collegiate Athletic Association.

Fulks, D. (2002b). Revenues and expenses of Division II intercollegiate athletics programs: Financial trends and relationships. Indianapolis, IN: National Collegiate Athletic Association.

Greene, W. H. (1997). Econometric analysis (3rd ed.). Upper Saddle River, NJ: Prentice Hall.

Johnson, J. K. (1994). Title IX and intercollegiate athletics: Current judicial interpretation of the standards for compliance. Boston University Law Review, 74, 553-589.

Leeds, M. A., Suris, Y., \& Durkin, J. (2004). College football and Title IX. In J. Fizel \& R. Fort (Eds.), Economics of college sports (pp. 137-151). Westport, CT: Praeger.

Mahoney, D. C. (1995). Taking a shot at the title: A critical review of judicial and administrative interpretations of Title IX as applied to intercollegiate athletic programs. Connecticut Law Review, 27, 943-977. 
Naughton, J. (1998, April 3). Women's teams in NCAA's Division I see gains in participation and budgets. The Chronicle of Higher Education. Retrieved October 6, 2005, from http://chronicle.com/che-data/articles.dir/art-44.dir/issue-30.dir/30a00101.htm.

Office for Civil Rights. (1979). A Policy Interpretation: Title IX and intercollegiate athletics. Retrieved October 6, 2005, from http://www.ed.gov/print/about/offices/ list/ocr/docs/t9interp.html.

Office for Civil Rights. (1996). Clarification of intercollegiate athletics policy guidance: The three part test. Washington, DC: U.S. Department of Education.

Office for Civil Rights. (2003). Further clarification of intercollegiate athletics policy guidance regarding the Title IX compliance. Washington, DC: U.S. Department of Education.

O'Neill, J. E. (1971). Resource use in higher education. Berkeley, CA: Carnegie Foundation.

Rishe, P. J. (1999). Gender gaps and the presence and profitability of college football. Social Science Quarterly, 80(4), 702-717.

Sabo, Don. (1997). The gender equity report card. East Meadow, NY: Women's Sports Foundation.

Shulman, J. L., \& Bowen, W. G. (2001). The game of life: College sports and educational values. Princeton, NJ: Princeton University Press.

Sigelman, L., \& Wahlbeck, P. J. (1999). Gender proportionality in intercollegiate athletics: The mathematics of Title IX compliance. Social Science Quarterly, 80(3), 518-538.

Stafford, S. (2004). Assessing the effect of formal and informal enforcement on progress towards Title IX compliance. Social Science Quarterly, 85(5), 1469-1486.

Suggs, W. (2004, June 18). Small colleges lag on sports opportunities for women. The Chronicle of Higher Education. Retrieved October 6, 2005, from http://chronicle.com/weekly/v50/441/41a00101.htm.

Thelin, J. (2000). Good sports? Historical perspective on the political economy of intercollegiate athletics in the era of Title IX, 1972-1997. Journal of Higher Education. 7l(4), 391-410.

Toma, J. D. (2003). Football U: Spectator sports in the life of the American university. Ann Arbor, MI: University of Michigan Press.

U.S. Department of Education. (1997). Title IX: 25 years of progress. Washington, DC: ED Pubs, Education Publications Center.

U.S. Department of Education, Secretary's Commission for Opportunity in Athletics. (2002). San Diego Town Hall Meeting Transcript, November 20, 2002. Washington, DC, 20202. Retrieved April 12, 2004, from http:/www.ed.gov/about/bdscomm/ list/athletics/transcripts.html.

U.S. Department of Education, Secretary's Commission for Opportunity in Athletics. (2003). Open to all: Title IX at 30. Washington, DC: ED Pubs, Education Publications Center.

Zimbalist, A. (1997). Gender equity and the economics of college sports. In W. Hendricks, (Ed.) Advances in the economics of sport (Vol. 2, pp. 203-223). Greenwich, CT: JAI Press.

Zimbalist, A. (1999). Unpaid professionals: Commercialism and conflict in big-time college sports. Princeton, NJ: Princeton University Press. 